
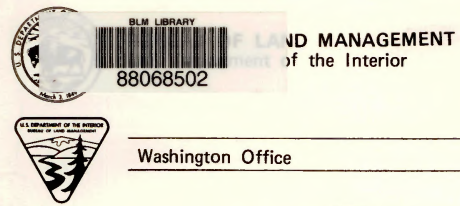

\begin{tabular}{ll} 
Washington Office & January 1989 \\
\hline
\end{tabular}
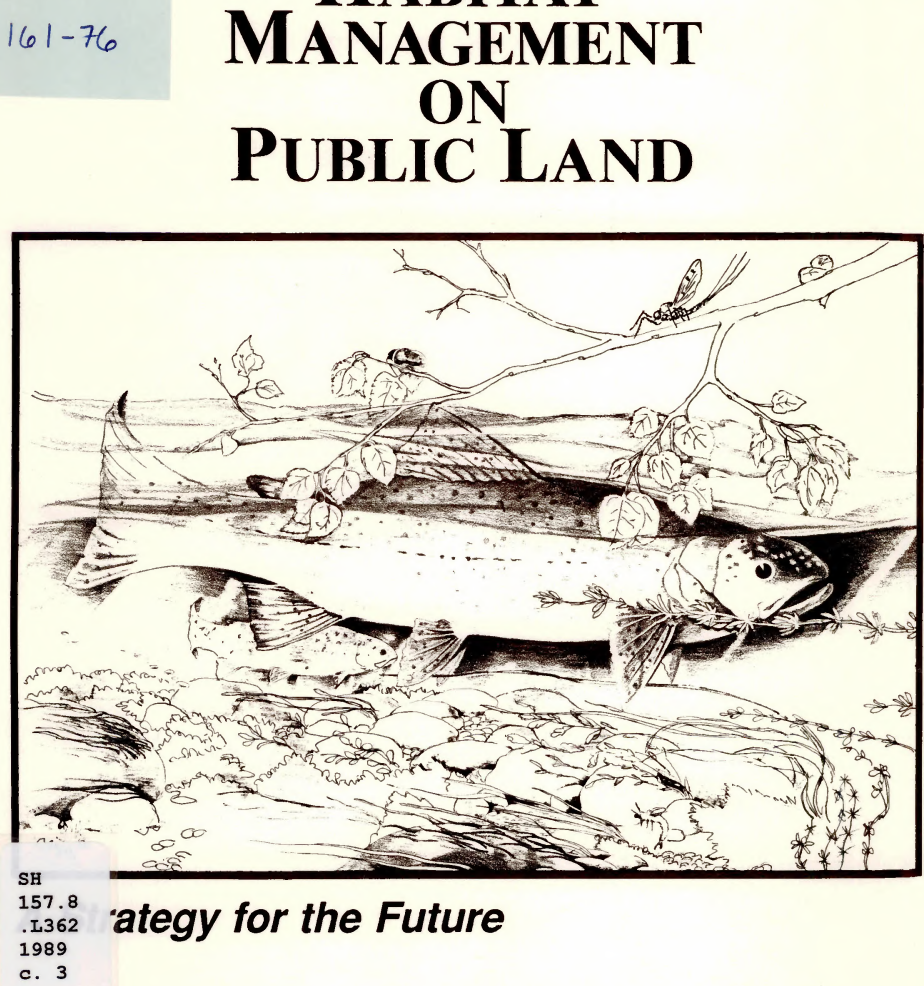



\title{
FISHERIES HABITAT MANAGEMENT ON PUBLIC LANDS A Strategy for the Future
}

\author{
January 1989
}

Prepared for the Director, Bureau of Land Management, Washington D.C.

\section{By the Bureau Fish Habitat Management Team:}

Del Vail, Idaho State Director, BLM, Team Leader Roger Bolstad, Kobuk District Manager, BLM James Moorhouse, Butte District Manager, BLM Paul Brouha, Deputy Director, American Fisheries Society Willie Molini, Director, Nevada Department of Wildlife Bill Geer, Director, Utah Division of Wildlife Resources Dave Almand, Chief, Division of Wildlife and Fisheries, BLM Paul Cuplin, Fisheries Biologist, BLM (Retired) Mike Crouse, Fisheries Program Manager, BLM Neil Armantrout, Eugene District Biologist, BLM Allan Thomas, Wildlife and Fisheries Program Leader, Idaho State Office, BLM 


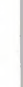




\title{
FISHERIES HABITAT MANAGEMENT ON PUBLIC LANDS
}

\author{
A Strategy for the Future
}

\section{Director's Preface}

The Bureau of Land Management has stewardship responsibilities for over 270 million acres of public lands held in trust for the American people. Under the Federal Land Policy and Management Act of 1976, these lands and their uses are to be planned for and managed under the principles of multiple use and sustained yield. Among the bountiful assets of the public lands are significant fisheries resources which are economically important and provide a wealth of recreational opportunities.

In May 1987, I approved "Fish and Wildlife 2000: A Plan for the Future," which sets forth national goals and objectives for more effective management of fish and wildlife resources on the public lands. In response to a proposal from the American Fisheries Society, I established a team to chart a course for achieving the fisheries program objectives outlined in "Fish and Wildlife 2000." The team was comprised of senior Bureau managers and biologists, the Directors of two State fish and wildlife agencies, and the Deputy Director of the American Fisheries Society.

Their report to mecandidly assesses the Bureau's existing fisheries program. To address the report's findings, the team developed a number of recommendations and specific actions needed to achieve a proactive, goal oriented fisheries program. Bureau managers will be instructed to use the resource related recommendations in their land use planning and to implement the other actions in ongoing management as appropriate. My guidance to managers will stress Bureau actions which facilitate on-theground accomplishments, particularly through resource management and more site specific activity planning. While many actions are already underway, it is anticipated that full implementation will occur over a period of years.

The recently adopted National Recreational Fisheries Policy declares: "A concerted and diligent effort is required to maintain, restore, and increase the productivity of the Nation's fisheries resources to provide for continuing public benefits." The Bureau, State fish and wildlife agencies, constituency groups, and individual anglers all have vital roles to play in cooperative fishery resource management efforts on public lands. The programmatic goals, objectives, and actions set forth in this report provide a solid foundation for each interest to build upon.

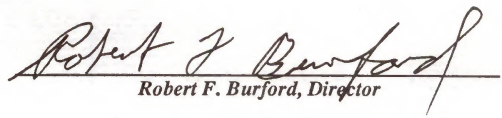


.

. 


\title{
FISHERIES HABITAT MANAGEMENT ON PUBLIC LANDS
}

\author{
A Strategy for the Future
}

\section{Executive Summary}

The Bureau of Land Management (BLM) manages over 85,000 miles of stream fish habitat, many lakes and reservoirs, and a wide variety of unique habitats. Fisheries resources managed by BLM on public lands contribute nearly $\$ 100$ million to the economy.

A variety of laws, Executive Orders and policy statements require BLM to manage fisheries and associated aquatic resources on a sustained-yield basis, within a multiple-use framework, without long-term loss of habitat capability, and with special attention given to aquatic resources with unique values. Policy direction is incorporated into resource management plans (RMPs) which prescribe general management practices and land use decisions for the management of fisheries resources. More detailed and sitespecific plans, including fish and wildlife habitat management plans, are prepared where necessary to help implement RMP decisions on the ground. Monitoring and evaluation are integral elements of all plans prepared.

In July 1987, the Bureau Director appointed a team of managers and biologists inside and outside the agency to review the Bureau's fisheries program and to develop recommendations and strategies to clarify and strengthen the program. The team found that during the past decade BLM has experienced a two-thirds reduction in fisheries biologist positions, leaving many field offices without adequate fisheries technical skills. This situation often puts the BLM in the position of conducting multiple-use management without representation from fisheries professionals and of being unable to capitalize on fish and riparian habitat improvement opportunities.

The reduction in fisheries personnel has resulted from a low priority for funding and a lack of understanding for the value of and need for fisheries resource management on BLM lands. These perceptual problems remain both inside and outside the Bureau. Even though BLM has recently made progress in coordinated riparian management, the overall condition of fisheries and aquatic resources on public lands has not improved.

The team has developed recommendations and an implementation plan of positive actions needed for BLM to meet legal mandates related to fisheries resources and guide future program development. In summary, the team recommends:

- Improving internal and external recognition of the value of Bureau's fisheries and associated aquatic resources.

- Ensuring that fisheries resources receive equal consideration with other resources in BLM's land use planning and budgeting processes.

- Increasing funding and positions sufficient to achieve a proactive fisheries program.

- Defining fisheries biologists' roles in the agency.

- Developing or improving fisheries program definition and support services.

- Developing habitat management plans (HMPs) in all basins and subbasins with significant fish habitat.

- Continuing development and improvement of cooperative management with state fish and wildlife agencies.

- Expanding participation of outside groups on fish and riparian habitat improvements through volunteer efforts and contributions. 


\section{TABLE OF CONTENTS}

\section{Introduction and Purpose}

Summary of Team Findings and Recommendations

The Program of the Future

Findings and Recommendations

Assessment of Existing Fisheries Program

Framework of Policy and Legislation

Fisheries Resources and Current Management Anadromous Fish Habitat

Resident Fish Habitat

Threatened and Endangered Species

Riparian Area Management

Existing Fisheries Program

Funding

Staffing

Program Perceptions

Planning Process

Support Services

Computer Services

Economic and Social Value

Staff Training

Studies and Research

\section{APPENDICES}

Appendix A - Annual Value of Fisheries on Public Lands

Appendix C - Policy and Legislation Relating to Aquatic Habitat

Appendix D - Summary of General Accounting Office

Appendix E - Fisheries Program History: Funding, Staffing, and

Appendix F - Attitudes and Perceptions Concerning the Fisheries Program

Appendix G - Comparison of BLM Fisheries Personnel versus Fisheries Habitat by State

Appendix H - Public Affairs Plan 



\title{
FISHERIES HABITAT MANAGEMENT ON PUBLIC LANDS
}

\author{
A Strategy for the Future
}

\section{INTRODUCTION AND PURPOSE}

Fisheries resources on lands administered by the Bureau of Land Management (BLM) are economically important to individuals and local communities, provide recreation to the American people, and contribute to the scientific and social well-being of the country. Over 58 million pounds of anadromous fish spawned on public lands in the Pacific Northwest are harvested by commercial fisherman at an annual market value of \$40 million. Approximately 3.5 million days of recreational fishing take place each year on public lands nationwide, valued at nearly \$56 million (see Appendix A). In addition, 99 fish species listed by the U.S. Fish and Wildlife Service as Threatened, Endangered, or Candidates are known to occupy the vast fisheries habitat on public lands (see Table 1).

Considerable effort has been expended in the past 20 years to maintain and increase habitat for natural production of fish spawned and reared on public lands. These efforts, however, have depended on the interest and capability of local field office staffs, and have not been well coordinated as part of a Bureauwide fisheries program. In May 1987, the BLM Director approved "Fish and Wildlife 2000: A Plan for the Future". This document, which received extensive internal and external review, sets forth programmatic goals and objectives for more effective management of fish and wildlife resources on public lands. In response to a proposal from the American Fisheries Society, the BLM Director established an interdisciplinary fisheries team to chart a course for achieving the fisheries program objectives outlined in "Fish and Wildlife 2000". This report, which was prepared by the Team, describes strategies for clarifying and strengthening the fisheries habitat program. It capitalizes on opportunities and details actions needed to build a management structure that will achieve a goal-oriented program.

Section II of this report characterizes BLM's future fisheries program and states Team findings and recommendations. The findings were based: 1) on existing information detailed in Section III concerning the extent, value, and current manage-

TABLE 1

AQUATIC HABITATS ON PUBLIC LANDS

(Source: Public Lands Statistics, 1986)

\begin{tabular}{|c|c|c|c|}
\hline $\begin{array}{c}\text { Administrative } \\
\text { State }\end{array}$ & $\begin{array}{c}\text { Lakes } \\
\text { looos acresl }\end{array}$ & $\begin{array}{l}\text { Reservoirs } \\
\text { (000s acres) }\end{array}$ & $\begin{array}{l}\text { Flshable } \\
\text { Streams } \\
\text { (Miles) }\end{array}$ \\
\hline Alaska & 3,874 & - & 65,000 \\
\hline Arizona & 1 & 28 & 439 \\
\hline California & 19 & 2 & 735 \\
\hline Colorado & 1 & 19 & 1,822 \\
\hline Idaho & 10 & 39 & 3,580 \\
\hline Montana & 26 & 22 & 1,132 \\
\hline Nevada & 23 & 5 & 1,134 \\
\hline New Mexico & 2 & 3 & 176 \\
\hline Oregon & 29 & 18 & 7,136 \\
\hline Utah & 5 & 8 & 2,300 \\
\hline Wyoming & 8 & 29 & 1.327 \\
\hline Total & 3,998 & 173 & 84,781 \\
\hline
\end{tabular}


ment of fisheries resources on public lands, and 2) through interviews with BLM managers and specialists, state fish and wildlife agency officials, and representatives of conservation groups. In Section IV, specific, positive actions are listed to implement the Team's recommendations.

\section{SUMMARY OF TEAM FINDINGS AND RECOMMENDATIONS}

\section{The Program for the Future}

The Team believes that "Fish and Wildlife 2000 " provides a solid foundation for development of a more realistic and responsive fisheries habitat management program. In addition, the team identified characteristics of the desired program for the future. In sum, the desired program should be:

- Supported by clearly defined structure and function, and by strong policy and direction.

- Accorded full consideration in the BLM's planning process.

- Supported by strong internal and external constituencies.

- In strong partnership with state fish and wildlife agencies and other organizations.

- Staffed with a highly qualified workforce at all levels that embodies appropriate knowledge, skills, and abilities.

- Adequately funded.

- Committed to development and maintenance of high quality data based on BLM's fisheries, riparian, and aquatic resources.

- Coordinated and consistent with other program efforts.

- Oriented to on-the-ground management and supported by applied research and studies.

- Proactive as well as reactive.

\section{Findings and Recommendations}

The Team identified ten findings concerning the fisheries program. Specific recommendations were developed to assist in the development of actions responding to each finding. The desired program characteristics (above) and the fisheries goals and objectives contained in "Fish and Wildlife 2000" (see
Appendix B) provide the framework for the Team's recommendations and for future efforts.

\section{Finding 1 (Policy and Direction):}

Although fish and their habitats on public lands are economically, recreationally, and scientifically valuable resources, they often do not receive equal consideration with other resources in land use planning and in multiple-use management.

\section{Recommendations:}

a. Build upon the efforts initiated in connection with "Fish and Wildlife $2000^{\prime \prime}$ to better define and describe its fisheries program.

b. Review existing policy and guidance for adequacy in ensuring that fisheries resources are recognized and fully considered at all levels of the planning process.

c. Ensure that fisheries-related allocations, objectives, and management directions are made during resource management planning as required by the Supplemental Program Guidance (MS 1622.1).

d. Incorporate fisheries and riparian resource management objectives, where appropriate, in site-specific activity plans.

\section{Finding 2 (Policy and Direction):}

Lack of clear-cut program goals and objectives in the past has contributed to inconsistent understanding, commitment, and support by field managers and others to fisheries resource management. Some have viewed the program as an unnecessary luxury, while others have recognized it as an important resource to be managed.

\section{Recommendations:}

a. Design and implement training/educational activities to improve field managers' understanding of the fisheries program, the priorities associated with it, and what can/ should be accomplished on the ground.

b. Stress the importance and high priority of fisheries during the budget planning process. 
c. Expand communication between field managers/offices and fisheries organizations to identify and implement cooperative projects and activities on the ground.

d. Clearly identify and document fisheries resource values, program objectives, and accomplishments to succeeding specialists and line managers to ensure continuity of fisheries programs at BLM district and area levels.

e. Review and revise Bureau manuals, handbooks, and other policy guidance to clearly define agency and individual roles and responsibilities related to aquatic resources.

f. Under the umbrella of the National Recreational Fisheries Policy, develop a BLM Recreational Fisheries Policy.

\section{Finding 3 (Cooperation and Education):}

Public perception is that BLM either lacks fisheries resources on the public lands it administers or has abdicated its management to others and is eliminating fisheries expertise in the agency. In most states and districts, BLM's fisheries program lacks a clearly defined constituency, so there are seldom advocates for the resource outside the Bureau.

\section{Recommendations:}

a. Promote participation of outside groups in fish and riparian habitat improvement through volunteer efforts and programs such as the Challenge Cost Share Program.

b. Expand and implement cooperative agreements such as those with the Izaak Walton League and Trout Unlimited for the enhancement of fish and riparian habitats.

c. Seek understanding by and support of BLM Multiple Use Advisory Councils (both national and district levels) and local Grazing Advisory Boards in fisheries/riparian project planning and development.

d. Expand public affairs efforts to tell the story of BLM fisheries resource opportunities to the public and intemal audiences through videos, slide shows, speakers, publications, etc.

e. Define and report program accomplishments in terms of fisheries benefits (e.g., new habitat units added, anglerdays increased, fishing access added) rather than in terms of how many fish biologists work for BLM or of how much money was spent on BLM's fisheries program.
Finding 4 (Administration and Support):

Professional fisheries staff in the BLM has declined by nearly two-thirds in the past decade. Consequently, fisheries expertise is not available in many of the field offices that have significant fisheries resources. This situation often puts the BLM in a position of conducting multiple use management without representation from fisheries professionals and of being unable to capitalize on fish and riparian habitat improvement opportunities.

\section{Recommendations:}

a. Identify field offices that are responsible for managing significant fisheries resources.

b. Recruit fishery biologists to serve those significant areas using a variety of staffing approaches.

c. Provide technical fisheries training for specialists in other disciplines and for managers who have fisheries duties and responsibilities in areas with significant fisheries resources and especially where there is little immediate likelihood for obtaining fisheries expertise.

d. Encourage sharing of technical expertise and information with state and other agencies.

\section{Finding 5 (Administration and Support):}

Less than four percent of the funds available to the BLM for management of lands and renewable resources are appropriated to the fish and wildlife program. Of this amount, less than 10 percent of BLM's fish and wildlife program funds and personnel are used for fisheries management. In addition, the fisheries program lacks a separate identify in tracking the use of funds and in recording accomplishments. This lack of identity and accountability often results in few specific fisheries-related items in annual work plans and in employee performance standards.

\section{Recommendations:}

a. Conductan analysis of fisheries resources and workload by state and district to determine appropriate distribution and levels of funding and staffing for fisheries habitat management.

b. Develop procedures for tracking fisheries program accomplishments and expenditures. 
c. Develop multi-year fisheries program action and funding strategies at the state and national levels and identify needs through the annual budget process.

d. Develop alternate funding sources and increased Congressional support (LWCF, BPA, Challenge Cost Shares, Sikes Act Habitat Stamps) to meet fisheries management needs.

\section{Finding 6 (Training):}

The fisheries workforce within the BLM is mature. Most biologists have been in place for several years, and career advancement opportunities for these biologists appear limited at present.

\section{Recommendations:}

a. Enrich work experience for BLM biologists by providing temporary assignments in various offices and in other disciplines to broaden their understanding of BLM operating and decision-making procedures in a multiple-use environment.

b. Promote communication skills training by encouraging active participation in professional societies and self-improvement programs.

c. Provide in-service training for entry-level fisheries biologists and continuing education for existing fisheries personnel to improve fisheries-related skills, knowledge of other resource disciplines, and awareness of agency program development and administration procedures.

\section{Finding 7 (Cooperation and Support):}

In field offices where fisheries expertise is available, cooperation and coordination with state fish and wildlife and other agencies concerning fisheries and riparian issues is generally good. These relationships, however, need to be strengthened in some areas to better utilize the personnel and resources in other agencies, especially in areas where no fisheries capability exists.

\section{Recommendations}

a. Ensure that state fish and wildlife agencies and other organizations are involved in planning and conducting fish and riparian habitat management and monitoring. b. Promote the active interchange of information and working relationships with other federal and state fish and game agencies through frequent coordination meetings, cooperative projects, joint inventory and monitoring programs, and field tours to discuss fisheries/riparian related issues.

c. Exchange personnel with other organizations under Interagency Personnel Agreements to broaden the technical and management knowledge of BLM fisheries and resource personnel and to improve understanding of BLM programs and procedures by state and other federal agency personnel.

d. Review national and state Memoranda of Understanding to ensure their adequacy in defining fisheries goals, objectives, and respective partnership roles.

e. Encourage state fish and wildlife agencies to contribute financial and personnel support to accomplish BLM fisheries program goals through Cooperative Agreements, Sikes Act Habitat Management Plans, and matching of Challenge Cost Share funds.

f. Cooperate with state agencies and other interested parties to identify and solve access problems which limit public use of BLM fisheries resources.

\section{Finding 8 (Administration and Support):}

Because of high values and public concern, considerable effort has been expended by BLM on anadromous fish habitats. Efforts related to the management of resident and threatened and endangered fish habitat, however, have been very limited because of inadequate funding, technical expertise, and program emphasis.

\section{Recommendations}

a. Fully implement the Anadromous Fish Habitat Plan by the year 2000.

b. Prepare a Resident Fish Habitat Plan with specific management goals and objectives.

c. Prepare a Threatened, Endangered, and Special Status Fish Habitat Plan with specific management goals and objectives.

\section{Finding 9 (Administration and Support):}

Aquatic resources data is not being collected, analyzed, 
and stored in a uniform, systematic manner. A major contributor to this lack of consistency among field offices is outdated or obsolete manual and handbook guidance related to inventory, monitoring, and enhancement of fisheries resources. As a result, valuable information is lost or underutilized, particularly in districts and states lacking fisheries expertise.

\section{Recommendations:}

a. Revise existing Bureau manuals, handbooks, and technical references related to inventory, monitoring, and enhancement of fisheries resources.

b. Develop and maintain standardized fisheries resources data bases at district and resource area levels to provide data needed for local and national planning and management purposes.

c. Collect, evaluate, and document information pertaining to recreational, subsistence, and commercial fisheries uses.

\section{Finding 10 (Administration and Support):}

Some BLM biologists are conducting fisheries studies and reporting results in scientific journals and at professional society meetings. Overall, however, fisheries research needs have not been identified, and the BLM's internal research project approval and tracking process discourages initiative by field biologists.

\section{Recommendations}

a. Identify applied research needs related to BLM fisheries management.

b. Support and cooperate with appropriate research by states, universities, and other agencies through financial and technical assistance and by encouraging research on public lands.

c. Ensure that results of BLM-sponsored studies are provided to field staffs and the scientific community through appropriate means such as workshops and field tours in addition to internal technical references, journal articles, and presentations at professional societies.

d. Review and improve the BLM's internal research proposal development, review, and feedback procedures.

\section{ASSESSMENT OF EXISTING FISHERIES PROGRAM}

\section{Framework of Policy and Guidelines}

The management of fisheries resources by the BLM is mandated by many Legislative Acts, Executive Orders, and Departmental Policy Directives (see Appendix C). Briefly, the BLM is directed to:

- Manage resources on a multiple-use, sustained yield basis.

- Maintain and improve fish habitat.

- Give priority to species listed under the Endangered Species Act, and to those which may become eligible for listing.

- Conduct and keep current an inventory of resources.

- Coordinate fisheries inventory, planning, and management with other federal and state agencies, local governments, and Indian tribes.

- Comply with appropriate state and federal pollution standards, and aid in the implementation of pollution abatement plans.

- Develop and implement fish habitat management plans as prescribed by resource management plans in cooperation with state fish and wildlife agencies and other interested publics.

- Monitor and evaluate management of aquatic resources.

- Protect wetlands and floodplains.

The BLM uses its manual to further detail this body of direction and to guide its implementation. Sections 6500 to 6900 of the manual pertain to wildlife and fisheries. Policy is expanded in the manual to require the BLM to manage fisheries resources: 1) in close cooperation with state agencies and other interested publics; 2) under principles of multiple-use, long-term sustained-yield, and sound management; and 3) to recognize populations and habitats requiring special attention. More detailed, technical guidance is provided by Bureau handbooks and technical references. The Team found that the majority of manuals, handbooks, and technical references related to the management of aquatic resources have been purged or are outdated. This lack of manual and handbook guidance is a major factor in the lack of clear direction and consistent implementation of the BLM's fisheries program.

Program emphasis and priorities are established by the Presi- 
dent and Congress through the annual budgeting process. Implementation of fisheries programs is through the Bureau planning and budgeting process. Because of the interaction among resources, the legal and policy mandates for the fisheries program are achieved primarily through implementation of RMPs and site-specific activity plans, i.e., timber management plans, grazing allotment management plans, and fish and wildlife habitat management plans.

\section{Fisheries Resources and Current Management}

\section{Anadromous Fish Habitat}

The BLM administers nearly 13,000 miles of spawning and rearing habitats for salmon and steelhead trout in five states: Alaska (at least 10,000 miles), California (190 miles), Idaho (1,300 miles), Oregon (1,400 miles), and Washington (50 miles). Over 58 million pounds of fish spawned on public lands are harvested by commercial fishermen at a current market value of $\$ 40$ million.

Since the 1870 s, the number of anadromous fish in the Pacific Northwest has declined nearly one-third from historic levels. Overharvest of some fish stocks has been a major factor in this decline, but the original productivity of many rivers and tributary streams has been substantially reduced due to human activities and land uses. Construction of hydroelectric and irrigation dams has blocked anadromous fish migrations to spawning and rearing areas. Timber harvest, grazing, agricultural development, channel alterations, road building, mining, and dredging and filling of estuaries have all contributed to reduced productivity of anadromous fish habitat.

In 1969 , following widely publicized problems arising from timber harvest practices in Pass Creek, fisheries biologists were hired in the five western Oregon BLM districts. The fisheries program in these districts has progressed from primarily log/debris jam clearance work and fish passage improvement projects to instream construction projects to improve or create spawning and rearing areas.

During the early 1980 s, the concerns of many people about the severe economic consequences of depressed wild coho populations resulted in Congressional funding to plan and design fish habitat improvement projects on public lands in coastal Oregon streams during FY 1985. As a result, the "Five-Year Comprehensive Anadromous Fish Habitat Enhancement Plan for Oregon Coastal Rivers" was developed. The BLM received $\$ 475,000$ in FY 1986 and $\$ 485,000$ in FY 1987 to complete priority projects listed in the 5-year enhancement plan. In FY 1987, the productivity of 14 miles of habitat was increased by the construction of 600 instream structures, 76 rearing pools, 5 off-channel developments, and one fish passage project. Much of the labor for these projects was contributed by volunteers from local sportsman groups, Boy Scout troops, and colleges.

In addition to habitat improvement projects, considerable progress has been made in altering timber harvest practices to protect fisheries resources on public lands. Vegetative strips are routinely left along fish-bearing streams to protect values associated with riparian areas. Practices that might degrade water quality and fish habitats, such as yarding logs through streams, are prohibited. Roads are designed to minimize the potential for erosion and sedimentation of fish-bearing streams.

Anadromous fish habitat management in other BLM states has been less aggressive, primarily due to lack of personnel, funding, and program emphasis. To develop a focused program Bureauwide and to implement the general goals and objectives in "Fish and Wildlife 2000 " related to anadromous fish habitats, a report titled "Anadromous Fisheries Habitat on Public Lands" was prepared.

This document establishes objectives (see Appendix B) for inventory, habitat project development and maintenance, improved management actions, monitoring, research, and habitat acquisition to be achieved in the next 12 years (1989 to 2000 ). It is estimated that full implementation of this plan would increase the number of anadromous fish produced on public lands by 20 percent, or 172,000 fish per year, resulting in returns greater than investment costs through benefits to recreational and commercial fishing. In addition to direct economic benefits to individuals and local communities, important sociological, biological, and scientific values will be realized.

\section{Resident Fish Habitat}

The resident fisheries habitat on public lands can be divided into three regions: Northwest, Mountain States, and Desert Southwest.

The Northwest region is composed of the States of Alaska, Washington, Oregon, and parts of California and Idaho. Resident species of interest include, but are not limited to, the Arctic grayling; rainbow, brown, cutthroat, and redband trout; and the black bass. The resident fisheries in the region are greatly overshadowed by the enormous anadromous fishery and economic values of anadromous species which dictate that greater effort be directed towards their management. Based on BLM "willingness-to-pay" statistics and the 1985 National Survey of Hunting and Fishing, over 1.5 million days of 
recreational fishing takes place for anadromous and resident fish each year on BLM-managed waters in these states worth $\$ 24$ million in primary benefits to fishermen.

In the Mountain region, composed of Colorado, Montana, Wyoming, and parts of Nevada, Idaho, Utah, and New Mexico, resident species of interest include the cutthroat, rainbow, and brown trout as well as a wide variety of cool/warm water species (bass, walleye, sauger, etc.). The Montana Department of Fish, Wildlife and Parks has identified 30 miles of "blue ribbon" trout streams on public lands, while the Colorado Division of Wildlife has classified 20 miles of "gold medal" waters and approximately 130 miles of "wild trout" waters on public lands. Resident fish of particular interest are several subspecies of interior cutthroat trout, which are found primarily in isolated headwaters of desert streams. Most of these cutthroat trout populations are given special status as Federally Listed Endangered and Threatened or Candidate species.

The Desert Southwest states are Arizona and parts of California, Nevada, New Mexico, and Utah. Although few large bodies of water are located on public land, there are numerous smaller ones which are habitat for the xeric-adapted native fishes. Many of these fish are included on the Federal Endangered Species List. The limited sport fish management that does take place is directed towards introduced warm water species such as bass and sunfish.

Thousands of reservoirs have been built on public lands, primarily to provide water for livestock. Many of these reservoirs retain sufficient water year-round to support game fish and are stocked by state fish and wildlife agencies.

Overall, these lakes, streams, and reservoirs managed by the BLM provide a major source of recreational fishing. A strategy should be prepared to address programmatic goals and objectives in "Fish and Wildlife 2000" and to provide recommendations for management of resident fisheries and fish habitat. It may be expected to address the objectives proposed in Appendix B.

\section{Threatened and Endangered Species}

The BLM manages habitat for 35 species of fish listed as Threatened or Endangered, and 64 species considered to be Candidate or Sensitive species. Most of these fishes are found in desert areas and have been isolated since the end of the last ice age. Because of their limited habitats, they are especially vulnerable to habitat changes. At present about one-half of these species are covered by recovery plans or habitat management plans, but only limited implementation has occurred due to the lack of funds, necessary technical skills, and support. Specific recommendations will be developed in a plan to be formulated for Threatened, Endangered, and Sensitive species. It may be expected to respond to the objectives proposed in Appendix B.

\section{Riparian Area Management}

Riparian vegetation is of critical importance for fish because the vegetation provides escape cover, lowers summer water temperatures through shading, and reduces streambank erosion that can silt in spawning and rearing areas. Healthy riparian systems also purify water as it moves through the vegetation by removing sediment and act as sponges by retaining water in streambanks and groundwater aquifers.

In 1985, the BLM undertook an initiative to focus appropriate attention and commitment on interdisciplinary management of riparian areas administered by BLM. Because of the many values and benefits of healthy riparian systems, the initiative emphasized a multidisciplinary approach to riparian management, involving not only the traditional programs such as wildlife, watershed, and soil management, but also range, forestry, lands, and recreation management. Actions set in motion by this initiative include:

- The FY 1986, 1987, and 1988 Annual Work Plan Directives to field of fices established management of riparian/wetland areas as one of the highest priorities in BLM's fish and wildlife, watershed, and range management programs.

- In 1987, the Bureau Director signed a Riparian Area Management Policy, which stresses the interdisciplinary, multiresource character of riparian area management.

- Several BLM state offices (Oregon, Montana, Utah, Arizona, and Wyoming) have developed Supplemental Riparian Policies, and all states have prepared Riparian Management Strategies.

- Public information materials on riparian management, including fact sheets, videos, slide shows, and displays, have been distributed to field offices.

- There has been increased "riparian consciousness" among BLM resource specialists and managers and public land users through BLM-sponsored workshops and tours.

- The Bureau Director has required that each district office develop at least one riparian demonstration area, where the best management practices and instream habitat improvement work have been or will be implemented.

The Team recognizes that the success of this initiative will have a very positive influence on the health of fish habitat 
throughout the BLM. Interviews with biologists and managers identified several key factors needed for successful riparian management programs at the field office level: 1) strong management commitment and support; 2) a coordinated effort by an interdisciplinary team with technical skills in range, forestry, hydrology, soils, wildlife, and fisheries management over an extended period; 3) public land users are informed about the multiple benefits of healthy riparian areas and are involved in management efforts; and 4) flexibility to alter stocking levels and grazing practices provided by having extra grazing capacity available. A recent Government Accounting Office report to Congress (see Appendix D), however, indicates that a lack of needed skills (particularly fisheries expertise), funding, training, and management commitment, aggravated in cases by political intimidation, is currently hindering the riparian initiative. These problems must be corrected if improvements in riparian and fish habitats are to be achieved.

\section{Existing Fisheries Program}

\section{Funding}

The budget appropriation for BLM's wildlife and fisheries management over the past nine years has averaged $\$ 15.4$ million annually and has ranged from $\$ 12.6$ million in FY 1980 to $\$ 18.5$ million in FY 1988 (see Figure 1). Funds and staffing allocated to the fish and wildlife programs comprise about four percent of the financial and personnel resources available to BLM for land and resource management programs (see Appendix E). Current accounting and reported units of program accomplishment do not allow ready separation of fisheries from wild life, but expenditures are estimated to be less that 10 percent, or about \$1.4 million for BLM's fisheries program. This does not include an additional estimated \$1.5 million for inventory, monitoring, and habitat improvements related to wetland/riparian areas which may benefit fish habitat.

\section{Staffing}

The number of fisheries biologist in BLM reached a high of 63 in the late 1970s and declined to 57 in 1980 and to 26 in 1987 (see Figure 2). The BLM hired many fisheries biologists in the 1970 s to provide fisheries resource input into required land use plans and National Environmental Policy Act documents. These documents were primarily prepared in support of grazing and minerals program requirements. Only limited funds were used for on-the-ground fisheries management. Biologists were not extensively involved in interdisciplinary teams developing and monitoring resource management practices. Once planning was completed, many fisheries positions were abolished or simply left vacant. Although funding for these positions by other programs was reduced, funding for the wildlife and fisheries program has remained relatively stable and has been sufficient to retain fisheries positions. Little effort has been made, however, at the field level to retain fisheries positions, indicating the low internal commitment to the program.

With a staff of 11 fisheries biologists, the fisheries program in Oregon remains the most active in the BLM. Oregon's success may be due to the active involvement of biologists in timber sale planning and monitoring; the high perceived value of the anadromous fish resources on public lands; and the extensive involvement of sportsmen and conservation groups in fish habitat improvement projects.

\section{Program Perceptions}

The BLM's fisheries program is not well understood or supported internally or externally.

Internal. Within the BLM, there seems to be support for a limited fisheries program, but not one that plays an active role in all aspects of land management decisions and activities. Interviews with BLM managers and biologists (see Appendix F) indicate that the fisheries program is often perceived as a luxury rather than a necessity. Many managers do not perceive aclear, defined program, a situation which often results in little or no accountability for the program or management of the resource. Specific goals or actions related to fish habitat management are rarely defined at the field office level, and few specific fisheries-related items show up in annual work plans or employee performance standards. In addition, the fisheries program is lumped within the wildlife program, thus losing separate identify and visibility. Fisheries personnel are generally not considered to be essential members of interdisciplinary teams; therefore, filling vacant fisheries positions is often a low priority.

External. Cooperation and coordination with state fish and wildlife and other agencies on fisheries and riparian issues is generally good in field offices where fisheries expertise is available. State agencies are encouraged by recent efforts such as "Fish and Wildlife 2000 " and the riparian intiative, but they remain skeptical of BLM's overall commitment to fisheries and riparian management. The relationship between the states and BLM needs to be strengthened in some areas to better utilize the personnel and resources in other agencies, especially in areas where no intemal fisheries capability exists.

Unlike the commodity resources, such as minerals and grazing, fisheries seldom has advocates for the resource outside BLM. The public is frequently not familiar with BLM and is 


\section{FIGURE 1}

\section{BUDGET HISTORY \\ WILDLIFE PROGRAM COMPONENTS}

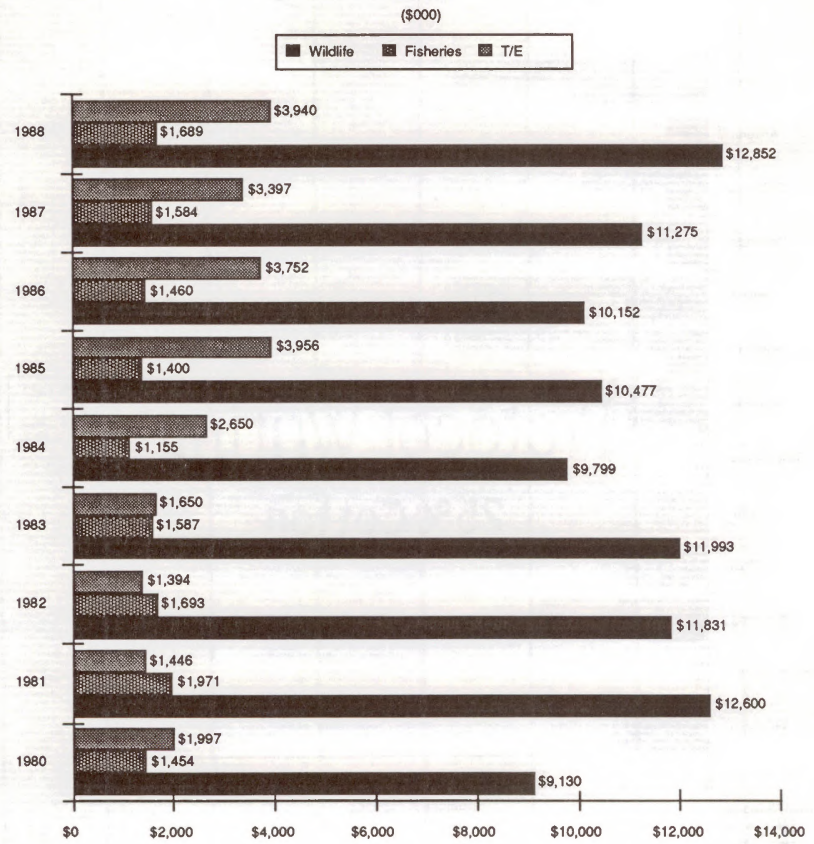




\section{FIGURE 2}

FISHERIES BIOLOGISTS BY STATE

CHANGE FROM 1980 TO 1987

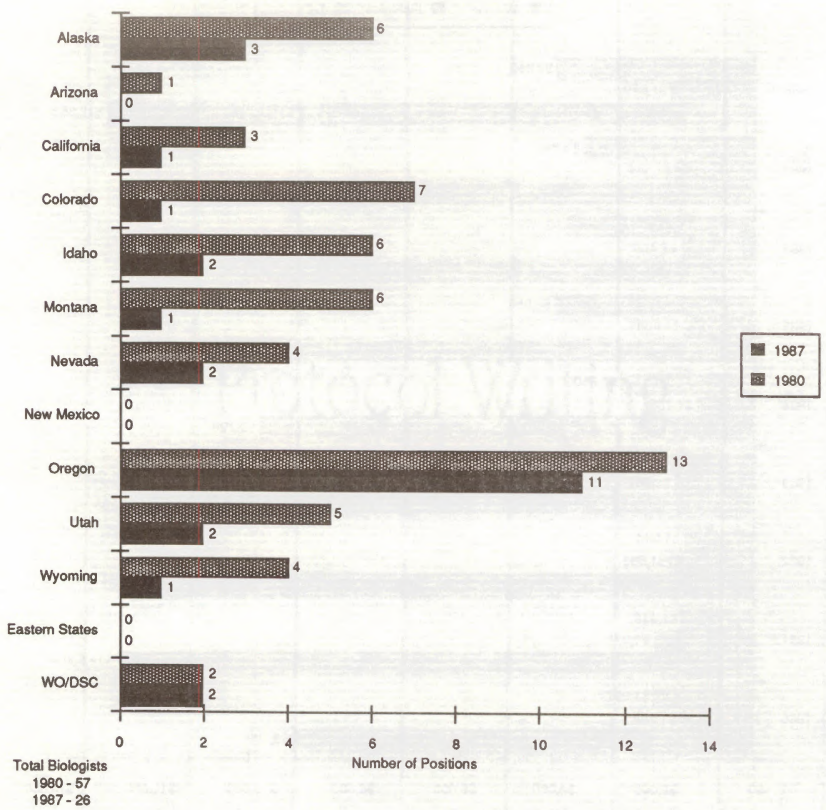


unaware that BLM has fisheries resources or habitat management responsibilities. Traditional users of the public lands, such as miners and livestock operators, often view fisheries management programs with distrust and uncertainty. In a few cases, however, successful fisheries and riparian programs have demonstrated that sound, cooperative management benefits all users.

A growing trend, more pronounced in some areas than in others, is the participation of sportsmen and conservation groups in BLM's fishery and riparian management programs. While these groups may lack the history of use of the traditional users, they often express the same proprietary interest and concern over the long-term use of the public lands and their resources. Many of their concerns and interests complicate management decisions because they conflict with those of the traditional users. Along with expressing their interests and concerns, many of these groups and individuals actively participate in BLM activities by providing time and money for fisheries enhancement projects. They represent a source of aid and support that can supplement appropriated BLM funding sources. The participation of these groups can be further enhanced by using Challenge Cost Share funds and coordinated resource planning. Fully utilizing this source of assistance will require working with these publics, involving them in decision-making, and providing for the necessary funding and personnel support in budget and annual work plan processes.

In summary, the Team identified a critical need for educating both BLM managers and the public concerning fish habitat potential of public lands and current BLM management activities.

\section{Planning Process}

Management of fisheries resources is guided by land use plans. Initial plans were commodity resource-oriented and were primarily for livestock, timber, and minerals. Current direction for planning focuses on a more integrated plan, called the resource management plan.

Existing land use plans may be amended to accommodate changes in policies and priorities; unanticipated proposals; and to add provisions previously not included.

Recently (1986) the Bureau Manual was amended to include Supplemental Program Guidance (SPG) for resource management planning. The SPG describes explicitly the allocations, objectives, and management directions for each program, including fisheries considerations, that must be addressed during resource management planning. To date it is unclear whether Bureau personnel with planning responsibilities are uniformly aware of this requirement. State Directors should ensure that fisheries related determinations are made during resource management planning.

While the resource management plan is the basic land use allocation document, most actions are guided by site-specific plans, such as allotment management plans or timber management plans. Since it is these site-specific plans that actually determine the on-the-ground management of aquatic resources, it is essential that fisheries expertise be included on interdisciplinary teams that develop, implement, monitor, and evaluate site-specific plans.

Site-specific actions for fisheries are most commonly through fish and wildlife habitat management plans (HMPs) developed and implemented under resource management plans. Most HMPs are completed under Sikes Act authority in cooperation with state agencies. Fish are the priority species in 106 existing HMPs, covering 3,100 miles of stream. This mileage represents less than 3 percent of the BLM's total stream miles containing fish habitat.

To date, approximately $\$ 10$ million, including $\$ 2$ million in donations of labor, materials, and money from groups interested in improving fisheries habitat, have been expended to implement these HMPs. However, it will require over \$21 million to fully implement existing fisheries HMPs.

Nearly one-half of the HMPs are for threatened and endangered species or candidate species; most of the remaining ones are for anadromous fish. If personnel and funding permit, an additional 31 new HMPs are proposed for completion in the next three years; 11 of these are for listed or candidate threatened and endangered fishes. This level of activity and proposed completion schedule will still leave most of the fish habitat, including that for about one-half of the Threatened and Endangered and Candidate fishes not covered by an HMP.

Lack of implementation funding remains a problem. Few of the HMPs have been fully implemented and many, including those for Threatened and Endangered and Candidate species, have not been started. Under BLM's planning system, HMPs should be developed for all basins with important fisheries resources.

\section{Support Services}

Many of the support services related to the fisheries program have developed locally on an ad hoc basis based on the interests and abilities of individual biologists. The Team identified four important support services which need improvement: 


\section{Computer Services}

Computers have increasingly become integral to the fisheries program. The BLM recently developed the Riparian Aquatic Information System (RAIDS), a computer storage and retrieval program designed to summarize inventory and monitoring information, but it is not yet widely used. A few individual offices have acquired computer systems and have developed their own programs. This individualized approach has resulted in limited Bureauwide compatibility. Because of this situation, aquatic resources data are not being collected, analyzed, and stored in a uniform, systematic manner, and valuable information is being lost or underutilized, particularly in districts and states lacking fisheries expertise.

\section{Economic and Social Values}

An integral part of preparing planning and National Environmental Policy Act documents is evaluating economic and social impacts. Biologists currently lack training in these subdisciplines to prepare adequate summaries. There is a need to: 1) develop improved methods for determining economic and social values and how these values would be affected by management actions, and 2) train biologists in developing these values and using them in BLM planning and decisionmaking processes.

\section{Staff Training}

Two types of training needs were identified by the Team: 1) continuing education and management training for fisheries biologists, and 2) technical fisheries training for personnel in other disciplines that have fisheries responsibilities and where there is little immediate likelihood for employing a fisheries biologist at their field location.

Universities do not always prepare biologists for the wide spectrum of issues encountered in a multiple resource management agency like BLM. Because of this fact, BLM offers several fish and wildlife courses at the Phoenix Training Center. The Center is currently developing two courses for managers and non-fisheries specialists related to riparian and fish habitat management. Such training will help managers understand the needs for considering aquatic resources in land management decisions and actions.

As mentioned earlier, the fisheries workforce with in the BLM is mature. Most biologists have been in place for several years and few new biologists are being hired. Career advancement opportunities for these biologists are limited. There is a need to enrich work experience for biologists by providing such opportunities as temporary assignments in various offices and in other disciplines to broaden their understanding of BLM operating and decision-making procedures in a multiple-use environment. Currently, the Phoenix Training Center is developing a course for mid-level fish and wildlife biologists designed to emphasize this concept. In addition, the American Fisheries Society and a number of universities and government agencies, such as the U.S. Forest Service, have developed continuing education courses for professional fisheries biologists which are available to BLM biologists. Finally, active participation in professional societies and self-improvement programs to improve speaking and writing skills should be encouraged.

\section{Studies and Research}

The BLM conducts only limited research. Research committees at the district and state levels provide guidance on needed research, and evaluate proposals submitted by employees, universities, and other agencies. The BLM collects considerable aquatic resource information of interest not only to other field offices but to scientists and managers outside the Bureau. The fisheries inventories, monitoring results, and HMP evaluations are examples of the types of activities that can provide useful information. However, needs or priorities for fisheries research have not been identified on a Bureau-wide basis. In addition, the current review, approval, and tracking process seems to discourage BLM employees from developing or conducting studies and research.

\section{IMPLEMENTATION}

Specific, positive actions needed to address Team findings and recommendations, and to achieve a proactive, goal-oriented fisheries program are listed in Table 2 . Implementation will be guided by the BLM's Washington Office Division of Wildlife and Fisheries through annual work plan priorities and other directives issued to the field, and by state "Fish and Wildlife $2000^{\text {" }}$ and riparian management strategies. While implementation will begin following approval of this strategy by the Bureau Management Team, it is anticipated that full implementation will occur over a period of years as recommendations are incorporated into the ongoing state, district, and area planning and budgeting processes. 
TABLE 2

POSITIVE ACTIONS FOR THE FUTURE

Action Respensibllity ${ }^{1} \begin{gathered}\text { Target } \\ \text { Date }\end{gathered}$ Recommendations Priority ${ }^{2}$

\section{Policy and Direction}

Issue Instruction Memorandum

WO 100

$7 / 88$

$1 b, 2 f$

to field endorsing National

WO 240

Recreational Fisheries Policy.

WO 340

Incorporate and highlight fisheries

related objectives in national and

WO 340

SO

state "Recreation 2000 " plans.

DO

Review Bureau policies related to

fisheries under the umbrella of the

WO 240

WO 340

$12 / 88$

$1 b, 2 f$

National Recreational Fisheries Policy.

Define Bureau fisheries mission and

program functions at each level of the organization and publish as a single document in the Bureau Manuals 6500 and 6760 .

Evaluate budget and other directives to ensure a distinct identity for the fisheries and wildlife programs.

Ensure that fisheries is included in the title of all $\mathrm{SO}$ and $\mathrm{DO}$ program leaders with significant fisheries resources.

$\begin{array}{rrr}\text { WO } 240 & 6 / 89 & 1 \mathrm{~b}\end{array}$

WO 240

$6 / 89$

$1 b, 2 f$

SO

$2 \mathrm{~b}, 2 \mathrm{e}$

WO 240

$6 / 89$

$1 \mathrm{~b}$

SO

b

Develop and maintain standard

fisheries resources data bases at the DO and RA levels.

Develop procedures and format to document values of fisheries resources on public lands.

SC 325B

DO

FY 90

$9 b$

RA

SC $325 B$

FY 89

$9 c$

WO 240

SO

Collect, evaluate, and document information pertaining to values of fisheries resources on public lands.

SO FY $92 \quad 9 c$

SC 325B

1 Organizational unit with lead responsibility listed first.

${ }^{2}$ Priority actions of highest importance and/or with the most important completion dates appear with three asterisks. 
TABLE 2 (CONTINUED)

\section{Action}

Review and revise existing manuals, handbooks, and technical references related to inventory, monitoring, and enhancement of fish habitats.

Ensure that fisheries-related allocations, objectives, and management directions are made during resource management planning as required by the Supplemental Program Guidance (MS 1622.1).

Incorporate riparian/fisheries objectives in all appropriate activity plans.

Prepare site-specific activity plans for all watersheds with important fisheries resources.

Implement Anadromous Fish Plan.

Prepare Resident Fish Plan with specific management goals and objectives.

Prepare T\&E Fish Plan with specific management goals and objectives.

Develop and/or revise state and district "Fish and Wildlife 2000" and riparian strategies.

\section{Administration and Support}

Develop a procedure that quantifies fisheries resources to help states determine staffing and funding levels.

Conduct fisheries workload analysis and recommend funding and staffing level to WO.

Adjust fisheries-related staffing and funding levels, as needed.
Target

Responsibillty

SC 325B

WO 240

SO

SO

Continuing

1c

SO

FY 89-92

DO

SO

FY $89-2000$

DO

RA

DO, RA

SO FY $89-2000$

Wo 240

FY 90

$8 b$

SC 325B

SO

WO 240

SO

SO

DO

10/89

1a, $5 c$

$8 c$

2d

SC $325 \mathrm{~B}$

WO 240

SO

2/89

$4 \mathrm{a}, 4 \mathrm{~b}$

$5 a$

SO

DO

$7 / 89$

$4 a, 4 b$

$5 a$

SO, DO

FY 89-92
$8 \mathrm{a}$

Prierity

$9 \mathrm{a}$

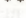

lc

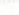

d

a

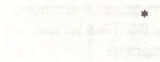

***

$4 a, 4 b$

$5 a$ 
TABLE 2 (CONTINUED)

\section{Action}

Develop system for reporting program accomplishments and expenditures.

Identify applied research needs related to fisheries/riparian management and develop proposals.

Review and improve the BLM's internal research proposal development, review, and feedback procedures.

Evaluate need for an intemal resource publication, i.e., Tech Notes.

\section{Cooperation and Education}

Request review of Team report by conservation and commodity groups, and state fish and wildlife agencies in key states.

Develop and implement national, state, and district public affairs plans to increase internal and public awareness of BLM's fisheries resources and program (see Appendix $\mathrm{H}$ ).

Review and revise fisheries-related Memoranda of Understanding with state fish and wildlife agencies and with other national, state, and local organizations.

Expand and implement cooperative agreements, such as with the Izaak Walton League, for the enhancement of fish and riparian habitats.

Establish similar national level cooperative agreement with Trout Unlimited.

Develop a plan for using volunteers in fish and riparian habitat improvement and maintenance.
Target

Responsibillty

Date

$6 / 89$

WO 240

WO 870

SC $325 B$, SO

Wo 709

WO 240

SC 325B, SO

WO 500

WO 709

SC $325 \mathrm{~B}$, SO

WO 709

WO 200

SO, SC $325 \mathrm{~B}$

10/89

$10 c$

WO 240

1/89

$3 d$

WO 240

$6 / 89$

3d

WO 130

SO, DO

PTC

WO 240

SO, DO

$10 / 89$

7d

SO, DO

FY 89

$3 b$

WO 240

$12 / 88$

$3 b$

SO, DO

$10 / 89$

WO 240

Team

$3 e, 5 b$

$10 \mathrm{a}, 10 \mathrm{~b}$

$10 \mathrm{~d}$

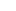

. 
TABLE 2 (CONTINUED)

\section{Action}

Develop alternate funding sources and Congressional support (LWCF, BPA, Sikes Act Habitat Stamps, etc.) to meet fisheries management needs.

Involve state fish and wildlife agencies and other organizations in planning and conducting fish and riparian habitat management and monitoring.

Cooperate with interested parties to identify and solve access problems which limit public use at BLM fisheries resources.

Include riparian and fisheries issues in frequent coordination meeting with state fish and wildlife agencies.

Seek support of BLM Multiple Use Advisory Councils and Grazing Advisory Boards in fisheries/riparian efforts.

\section{Training}

Develop and conduct training in fisheries/riparian management for non-fisheries specialists and managers.

Provide training for mid-level biologists to update fisheries skills.

Provide alternate work assignments for fisheries workforce to broaden experience and understanding of the BLM's multiple-use decisionmaking processes.

Improve communication skills by encouraging biologist participation in professional societies and public speaking and instructor training.
Besponslbillity Target

WO 240

Continuing

SO, DO

SO, DO Continuing
SO, DO Continuing
RA

SO, DO

Continuing

SO, DO Continuing

PTC

WO 240

WO 220

PTC WO 240

SO

SO, DO

WO 240

WO 833

WO 240

PTC

WO 833

SO, DO
Date

$7 \mathrm{a}$

$7 \mathrm{~b}$

FY $89-90$

Fy $89-90$

$6 a$

Team

\section{Becommendations Prlority}

$5 d$

$7 f$

7c

$2 \mathrm{a}, 4 \mathrm{c}$

$6 c$

FY 89-92

$6 b$ 


\title{
TABLE 2 (CONTINUED)
}

$\begin{array}{lcccc}\text { Action } & \text { Responsibllity } & \begin{array}{c}\text { Target } \\ \text { Date }\end{array} & \begin{array}{c}\text { Team } \\ \text { Recommendations }\end{array} & \text { Prlority } \\ \text { portunities for personnel } & \text { WO } 240 & 10 / 89 & 7 \mathrm{c} & * \\ \text { g., Interagency } & \text { WO } 833 & & & * \\ \text { greement) with state fish } & \text { SO } & & & \end{array}$

Evaluate opportunities for personnel exchange (e.g., Interagency

Personnel Agreement) with state fish and wildlife agencies and other

organizations.

\author{
Abbreviations \\ WO 100 Washington Office - BLM Director \\ WO 130 Washington Office - Public Affairs \\ WO 200 Washington Office - AD-Lands and Renewable Resources \\ WO 220 Washington Office - Division of Rangeland Resources \\ WO 240 Washington Office - Division of Wildlife and Fisheries \\ WO 340 Washington Office - Division of Recreation, Cultural, and \\ Wilderness Resources \\ WO 500 Washington Office - Program Evaluations \\ WO 709 Washington Office - Resource Science Staff \\ WO 833 Washington Office - Employee Development and \\ Performance Improvement \\ WO 880 Washington Office - Division of Budget \\ SO State Office(s) \\ DO District Office(s) \\ RA Resource Area Office(s) \\ SC 325B Denver Service Center, Division of Resources \\ PTC Phoenix Training Center
}







\section{APPENDICES}

Appendix A - Annual Value of Fisheries on Public Lands

Appendix B - Fisheries Goals and Objectives

Appendix C - Policy and Legislation Relating to Aquatic Habitat Management

Appendix D - Summary of General Accounting Office Text Concerning Riparian Management

Appendix E - Fisheries Program History: Funding, Staffing, and Accomplishments

Appendix F - Attitudes and Perceptions Concerning the Fisheries Program

Appendix G - Comparison of BLM Fisheries Personnel versus Fisheries Habitat by State

Appendix H - Public Affairs Plan

Appendix I - Fisheries Team Members 


\section{APPENDIX A}

\section{ANNUAL VALUE OF RECREATIONAL FISHERIES \\ PUBLIC LANDS - 1986}

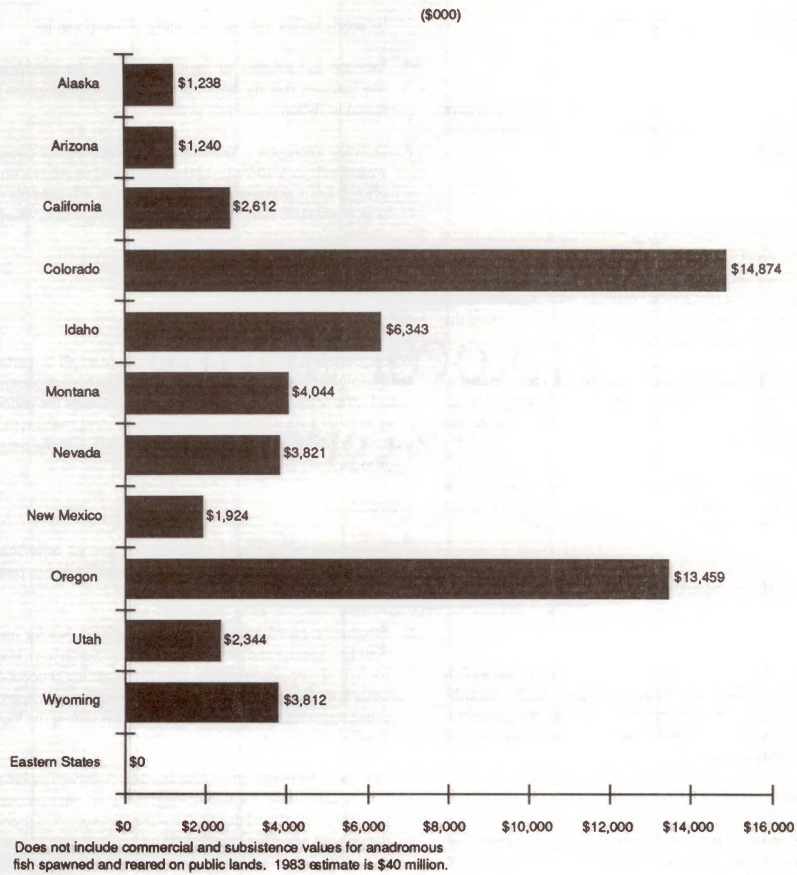




\section{APPENDIX B \\ FISHERIES GOALS AND OBJECTIVES "FISH \& WILDLIFE 2000"}

\section{Riparian Area Management}

\section{Goal}

Manage riparian areas to achieve a healthy and productive condition for long-term benefits and values, in concert with the range and watershed programs.

\section{Objectives}

1. Maintain and, where necessary, restore riparian areas via an interdisciplinary approach and participative effort in allotment management plans, habitat management plans, and other appropriate plans in accordance with schedules and decisions resulting from the Bureau planning system at the state, district and resource area levels.

2. Monitor important riparian/wetland areas under management and other areas with identified conflicting uses according to schedules developed by state, district, and area office managers.

3. Implement riparian management, protection, and restoration efforts so that at least 75 percent of riparian areas are in good or better ecological condition by 1997.

\section{Anadromous Species}

\section{Goal}

Provide and enhance the fisheries potential of anadromous fish streams in the Pacific Coast drainages so as to further contribute to the public use and enjoyment and to the economic stability of coastal communities and to the recreational and commercial fishing industries.

\section{Objectives}

1. Identify, where it has not already been done, streams that support anadromous fish at the state, district, and resource area levels in California, Oregon, Idaho, and Alaska.

2. Increase habitat productivity in streams currently utilized by anadromous fish but producing below potential.

3. Increase the amount of habitat available for producing anadromous fish by completing fish passage projects as stated in fisheries activity plans.

4. Develop interagency habitat management plans for coastal watersheds in California and Oregon and in Alaska on a priority basis as agreed toby appropriate BLM state offices, concerned state and local agencies, and major landowners.

\section{Resident Species}

\section{Goal}

Manage habitat for resident species that spend all or part of their life cycles on public lands and that are of high economic, social, or scientific value to local communities or the nation. This includes both warm and cold water resident species, such as bass, rainbow, and cuthroat trout, and fishes in the desert Southwest.

\section{Objectives}

1. Implement current land use plans for species or habitats identified as important to local communities within timeframes established by BLM managers.

2. Emphasize coordinated management approaches for resident fish species and their habitats, where needs have been identified through the BLM land use planning process or other appropriate procedures, by cooperating with appropriate agencies, organizations, and landowners at the local level.

3. Maintain or enhance important resident fisheries resources by implementing habitat management or improvement projects as identified during the planning process in accordance with priorities established by management.

4. Secure access to sport fishing waters on the public lands by working with private landowners, and other concerned agencies and organizations to identify access problems and 
solutions at the state, district, and resource area levels, according to a schedule developed jointly by BLM state offices and state fish \& wildlife agencies.

\section{Anadromous Fish Plan Objectives}

1. By 1994 , inventory and evaluate 3,480 miles of anadromous streams on public lands in Oregon, Washington, California, Alaska, and Idaho for habitat condition and improvement potential.

2. By 2000 , improve 464 miles of anadromous streams through development of new habitat improvements and maintenance of existing projects.

3. Enhance or protect all anadromous streams on public lands by implementing land management practices.

4. Prepare habitat management plans for management of anadromous fish habitats, and develop 15 cooperative habitat management agreements/plans on high priority watersheds in cooperation with major landowners and government agencies and private interest groups.

5. Monitor high priority anadromous fish habitats to provide managers with timely and adequate information needed to make land use allocation decisions.

6. Conduct or support research and studies needed to improve management of anadromous fish habitats and determine the effectiveness of habitat improvements.

7. Acquire 86 miles of important anadromous fish habitat through exchange or other means.

\section{Proposed Resident Fish Plan Objectives}

1. Inventory and evaluate resident fish habitat on public lands for habitat condition and improvement potential.

2. Develop and implement habitat management plans for riparian areas, lakes, and reservoirs in order to restore and maintain habitat and to realize the recreational potential of these areas.

3. Cooperate with states and user groups to maintain, develop, and improve resident fisheries and fish habitat.

4. Develop recommendations for land purchases and exchanges in order to provide better habitat and recreation management.
5. Monitor resident fish habitat subject to change as a result of resource use and development to provide information needed for managers to adjust practices and land use allocations.

6. Define research needed to manage resident fish habitat.

\section{Proposed T\&E and Sensitive Fish Plan Objectives}

1. In cooperation with the U.S. Fish \& Wildlife Service and state agencies, develop and implement recovery plans or habitat management plans for all listed species and their habitat.

2. In cooperation with the U.S. Fish \& Wildlife Service and state agencies, develop and implement habitat management plans or other formal management plans for sensitive or candidate species and their habitat in order to maintain or improve existing habitat conditions and populations.

3. Identify and develop management plans for populations of fishes with unique genetic characteristics, particularly the isolated populations of salmonids.

4. For habitats of limited size and distribution, develop and implement habitat management plans or Areas of Critical Environmental Concern to maintain or improve the habitats and associated aquatic flora and fauna.

5. Utilize land exchanges, acquisition, or cooperative agreements, including stewardship agreements, with other organizations or landowners to ensure management of sensitive habitats.

6. Participate in cooperative studies on genetic uniqueness of populations, reintroductions of fishes into historic habitat; habitat requirements of Sensitive and Listed species; habitat restoration techniques; and habitat ecology of Sensitive and Listed species. 


\section{APPENDIX C \\ POLICY AND LEGISLATION RELATING TO AQUATIC HABITAT MANAGEMENT}

There are at least 30 Legislative Acts, six Executive Orders and several Bureau manual sections that provide direction to BLM for the management of aquatic resources on public lands.

The major impetus for hiring fisheries biologists within BLM was the National Environmental Policy Act of 1969, which required the agency to do environmental assessments of land management plans and other actions.

With the passage of the Federal Land Policy and Management Act of 1976 (FLPMA), BLM received for the first time permanent authority to retain and manage resources on public lands, including fisheries, for multiple uses. FLPMA provided a broad legal framework for management of the public lands and remains the basic guidance for management of fish and wildlife habitat on public lands. Specifically, FLPMA:

- Requires the development and maintenance of land use plans based on an inventory of all public lands and their resources.

- Places fish and wildlife management on an equal footing with other traditional land uses.

- Requires that part of grazing fees be spent for "range betterment," including aquatic and terrestrial wildlife habitat enhancement, protection, and maintenance where livestock use occurs.

- Requires consideration of fish and wildlife resources before approval of land exchanges.

- Authorizes the designation of Areas of Critical Environmental Concern to protect and prevent irreparable damage to fish and wildlife, and other resources.

- Neither enlarges nor diminishes the responsibilities and authorities of the state for management of fish and resident wildlife.

- Authorizes investigations, studies, and experiments involving the improvement, management, use, and protection of the public lands and their resources.
Two other Acts have played major roles in BLM's fisheries program. The first is the Sikes Act of 1974 , which was a congressional mandate for BLM to "plan, develop, maintain, and coordinate programs for the conservation and rehabilitation of wildlife, fish, and game." The Sikes Act is currently being implemented through the development of habitat management plans in cooperation with the states.

The second is the Endangered Species Act of 1973, which provides for the protection of listed and potentially listed species and their habitats. Many of the listed fish species in the West are on lands managed by BLM.

The one exception to basic legal guidelines is the Oregon and California (O\&C) lands of western Oregon, which are managed under the O\&C Act of 1937. FLPMA states that whenever inconsistencies or conflicts arise between FLPMA and the O\&C Act, the O\&C Act shall prevail. The O\&C Act does not mention fisheries habitat directly, but does state that the lands shall be managed to protect watersheds, regulate stream flow, contribute to local economic stability, and provide for recreation. These mandates have been used to support the habitat management for the important anadromous species that inhabit streams on $\mathrm{O} \& \mathrm{C}$ lands.

Legislative Acts related toaquatic resources have been supplemented by a number of Executive Orders, the most pertinent of which are:

- EO 11514, Protection and Enhancement of Environmental Quality, which states that federal agencies shall "monitor, evaluate, and control on a continuing basis their agencies' activities so as to protect and enhance the quality of the environment."

- EO 11988, Floodplain Management, which directs federal agencies to "take action to reduce the risk of flood loss, to minimize the impact of floods on human safety, health, and welfare, and to restore and preserve the natural beneficial values served by floodplains...."

- EO 11990, Protection of Wetlands, which directs each agency to "provide leadership and take actions to minimize 
the destruction, loss or degradation of wetlands, and to preserve and enhance the natural and beneficial values of wetlands...."

The BLM uses its manual series to provide detailed policy and guidance for implementation of legal guidelines and policy documents. The 6500 to 6900 series covers the wildlife and fisheries portion of the manual. Pertinent guidelines for the fisheries habitat program based upon the various Legislative Acts, Policy Directives, and manuals are summarized below:

- Resources are to be managed on a multiple-use and sustained-yield basis, using adequate inventory information to develop interdisciplinary and site-specific habitat plans.

- An inventory is to be made of all resources, considering present and future uses. The inventory is to be kept current to reflect changing conditions.

- All inventories, planning, and management is to be coordinated with other federal and state agencies and local governments and Indian tribes.

- The quality of the environment is to be protected and, where appropriate, to be preserved and protected in its natural condition. Priority is to be given to protecting critical habitat for Threatened and Endangered species and Areas of Critical Environmental Concem.

- Species listed as Threatened or Endangered, or which are designated as Candidate species, are to receive special protection. Any actions that may detrimentally impact these species will be reviewed by the U.S. Fish and Wildlife Service under a formal consultation process.

- Fish habitat and resources are to be protected from irreparable damage.

- Comply with appropriate state and federal pollution standards, and aid in the implementation of pollution-related plans

- Habitat management plans for site-specific actions are to be prepared in partnership with state agencies. States have primary responsibility for management of species unless Congress directs otherwise. BLM is to coordinate multipleuse with appropriate state fish and wildlife agencies and other concerned organizations.

- Activities are to be monitored, evaluated and controlled on a continuing basis in order to protect and enhance the quality of the environment.

In summary, Legislative Acts, Executive Orders, and Depart- mental and Bureau policies require that the BLM manage fisheries resources: 1) in close cooperation with other organizations, 2) under principles of multiple use, long-term sustained yield, and sound management practices, and 3) recognizing populations and habitats requiring special attention. 


\section{APPENDIX D \\ SUMMARY OF GOVERNMENT ACCOUNTING OFFICE TEXT CONCERNING RIPARIAN MANAGEMENT}

The perceptions of BLM's fisheries program are supported by the testimony given by a Government Accounting Office (GAO) team before the House Subcommittee on National Parks and Public Lands, March 1, 1988. The GAO report found that overall riparian condition on public lands is poor, primarily due to poor grazing management. Some examples of good management were found. Of these examples, GAO stated:

"Although the fundamental solution - better livestock management - was uniform across all the projects we examined, the projects also demonstrate that successful restoration involves the application of site-specific approaches that take into account the type of ranching operation and such characteristics of the area as temperature, rainfall, and soil type. Developing site-specific solutions, carrying them out, and monitoring the results requires the knowledge and skills of specialists such as wildlife and fisheries biologists, hydrologists, range conservationists, and soil scientists.

"While the successes to date are encouraging and demonstrate in dramatic terms what can be accomplished, these successes represent only a fraction of the areas still needing restoration. BLM does not have complete inventories of the amount and condition of riparian areas throughout the West, but the partial information that is available shows that there are tens of thousands of miles of riparian areas in the West with only a small portion of them in good condition."

As the GAO report goes on to state, "BLM has issued a riparian area policy statement that endorses riparian improvements. At the same time, however, it has substantially reduced the number of skilled staff necessary to develop the site-specific strategies for implementing the policies. For example, between 1980 and 1986 staffing levels of wildlife and fisheries biologists were reduced by 26 and 43 percent, respectively."

As noted by the team, the loss of expertise is not due simply to a lack of funds, but is more a reflection of the lack of acceptance of an active fisheries program. One of the findings of the GAO report was that, even when skills are available, there is a lack of management support. Specifically, "The widespread perception by BLM field staff that their efforts will not be supported is having a chilling effect on the individual initiative so necessary to successful riparian improvement efforts." 


\section{APPENDIX E}

\section{FIGURE 1 \\ BUDGET HISTORY \\ WILDLIFE PROGRAM COMPONENTS}

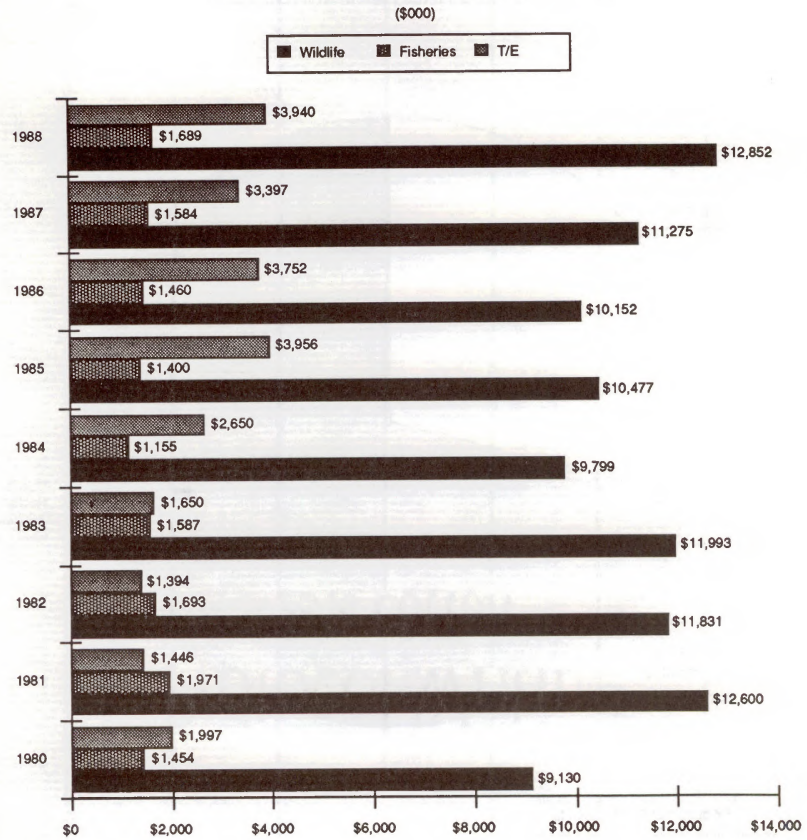




\section{APPENDIX E (CONTINUED)}

\section{FIGURE 2 \\ DISTRIBUTION OF FY 1987 EXPENDITURES \\ BY PROGRAM ELEMENT FOR FISHERIES HABITAT MANAGEMENT}

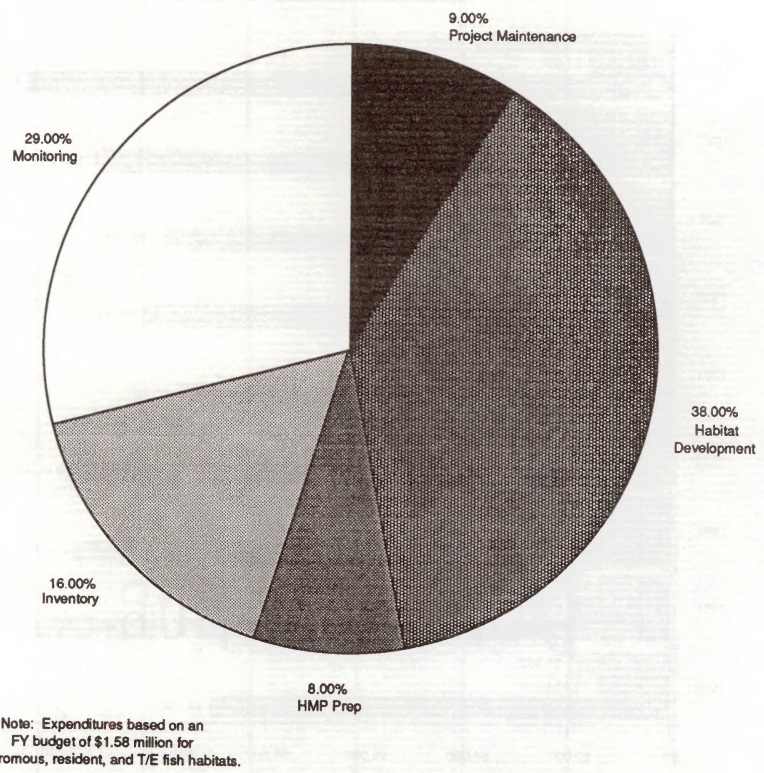




\section{APPENDIX E (CONTINUED)}

FIGURE 3

FISHERIES BIOLOGISTS BY STATE

CHANGE FROM 1980 TO 1987

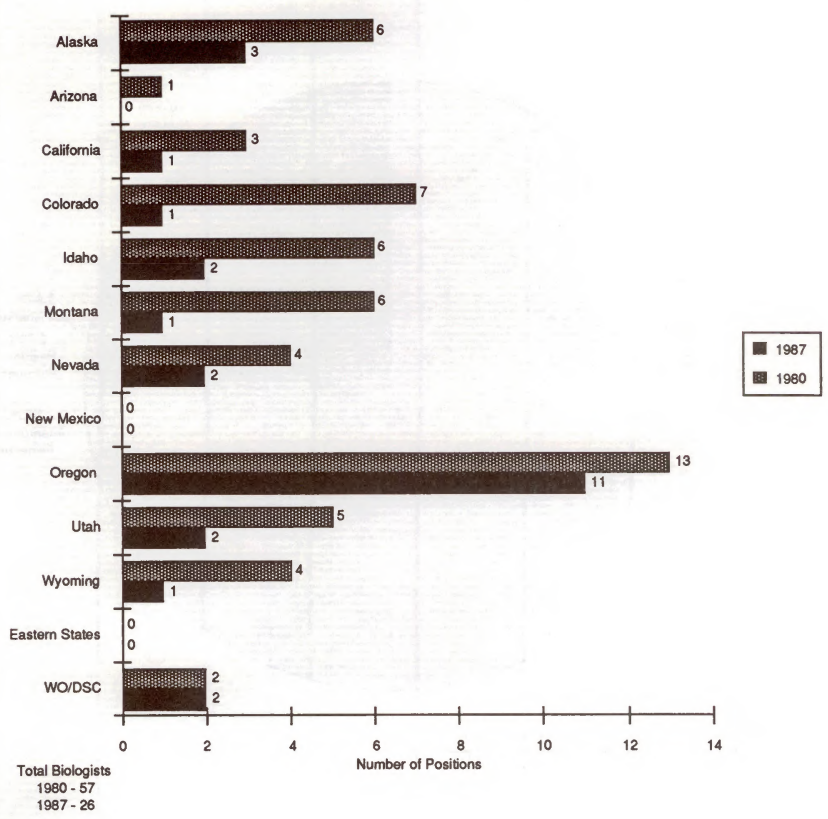




\section{APPENDIX E (CONTINUED)}

\section{FIGURE 4 \\ COMPARISON OF FISHERIES BUDGET TO TOTAL WILDLIFE BUDGET AND HOW FISHERIES FUNDS WERE USED - 1987}

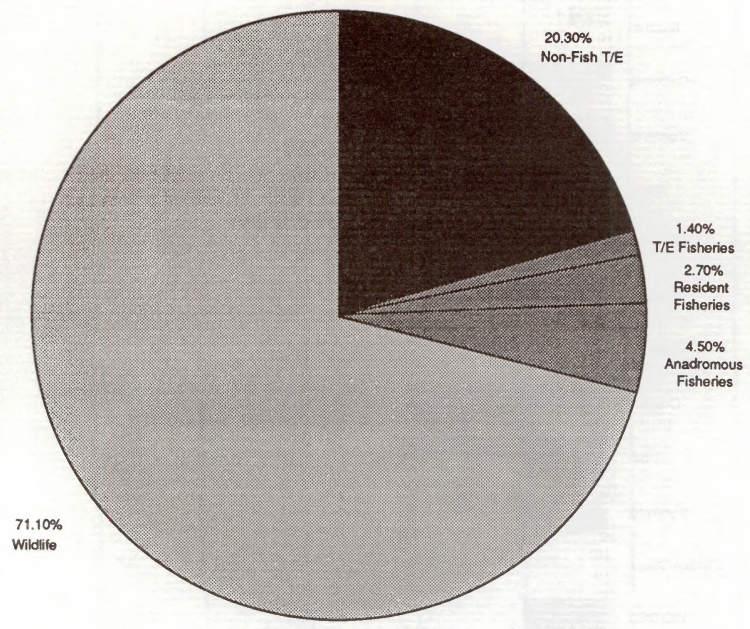

Based on a total FY 1987 appropriation of $\$ 17.5$ million for fish and wildlife (includes $\$ 1.2 \mathrm{million}$ for fish and wildlife on $\mathrm{O} \& \mathrm{C}$ lands in Oregon). 


\section{APPENDIX E (CONTINUED)}

FIGURE 5

UNITS OF ACCOMPLISHMENT FOR ANADROMOUS

RESIDENT AND T/E FISH - FY 1987

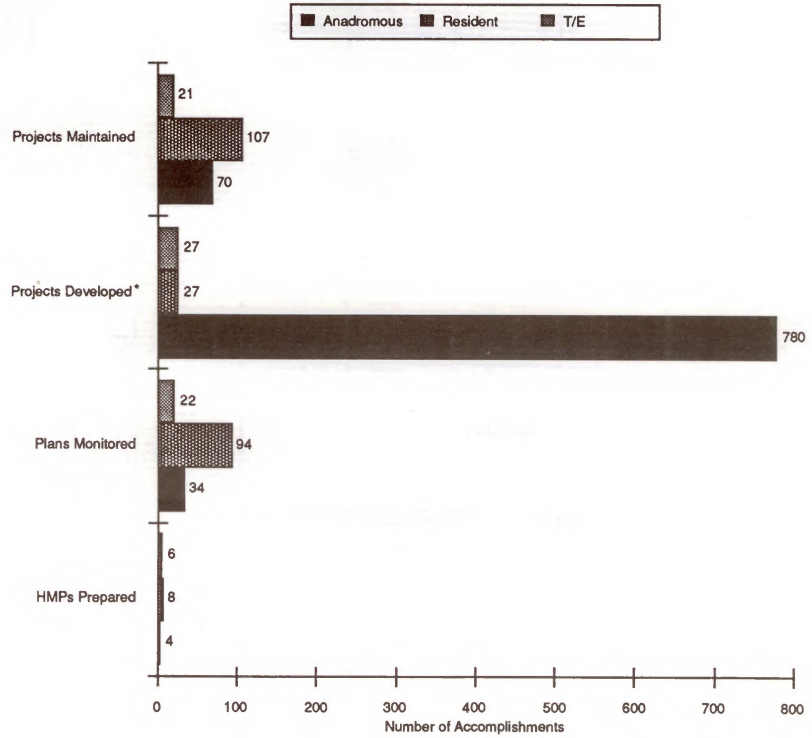

-Fisheries projects include construction of instream structures,

placement of habitat boulders, fish passage improvements, bank restorations,

cleaning of spawning gravels, riparian vegetation enhancement, etc. 


\section{APPENDIX E (CONTINUED)}

FIGURE 6

FISHERIES PROGRAM EXPENDITURES

BY STATE - 1987

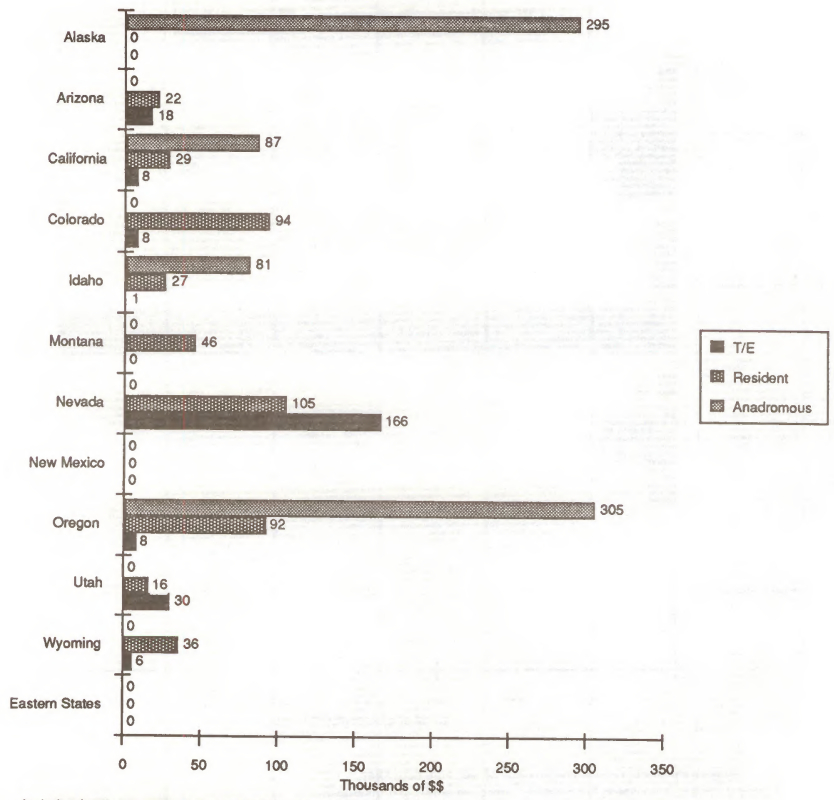

Includes $\$ 305,000$ appropriated in O\&C funds for anadromous fish habitat management in Oregon 


\section{APPENDIX F \\ ATTITUDES AND PERCEPTIONS CONCERNING THE FISHERIES PROGRAM}

During BLM's "Fish and Wildlife 2000 " implementation workshop held in Phoenix in December 1987, a group of managers and biologists from nearly every BLM state met to provide their perceptions of attitudes and emphasis, both internally and externally, toward fisheries and riparian management in the BLM. The following is a summary of the group's comments concerning fisheries:

- The fisheries program is often perceived as a luxury rather than a necessity. While there may be many fish, wildlife, watershed, and similar values, they are not perceived as returning money or other definable benefits to the BLM. Therefore, the fisheries program is seen by some as a cost rather than an asset and therefore not vital to the BLM's mission.

- The fisheries program is lumped within the wildlife program, thus losing separate identity and visibility.

- The managers have not perceived a clear, defined program in past years. Many of the fisheries positions were added as a result of NEPA and were paid for with funds from other programs (such as minerals). Once the planning process was over, retaining the fisheries positions was seen as a low priority since it lacked a separate program identity or clearly defined program goals and objectives.

- Managers often did not know of or acknowledge the resources on their lands. It was noted that in those instances where managers became knowledgeable about fisheries values, they became much more supportive of the program.

- Managers have had little or no accountability for the program or management of the resource. There are few specific goals or actions defined, and few fisheries related items show up in performance improvement and position reviews (PIPRs) or annual work plans (AWPs) in a precise way. Without accountability, fisheries has become a program that is done when possible. But little or no negative feedback results from failure to achieve fisheries goals.
- Land ownerships are often fragmentary, and there is a perception that because of the limited ownership, The BLM has little opportunity for fisheries habitat management.

- Public perception is that BLM has no fisheries resources. State agencies and the U.S. Forest Service are seen as taking care of any fish resources in the state; BLM is seen as either lacking resources or abdicating its management to others.

- In most states and districts fisheries lack a clearly defined constituency. While other resources, such as minerals and range, have well defined constituencies, fisheries doesn't. As a result there are seldom advocates for the resource outside the BLM.

- There is a perception that some BLM fish habitat projects are overly expensive and unnecessary.

- Although BLM as a whole has a negative image among the conservation community, certain programs and individuals in the BLM have a very positive image. These successful efforts are seen by some as occurring in spite of, rather than as a result of, BLM policies.

- Riparian area management is now a national issue. Conservation groups are actively working for changes in the legal and policy framework related to riparian management at the national level, and there is a similar constituency growing in many states and districts.

- As a result of the Riparian Policy, BLM has been working more cooperatively with conservation groups, particularly at the national level.

- Among state agencies and conservation groups, the apparent improvements are seen as positive, and these groups support BLM's initiatives. Many groups, however, remain skeptical of the BLM's overall commitment to riparian management.

- There is confusion among many BLM employees about the BLM riparian management initiative. The definitions of 
riparian, the goals of riparian management, the requirements of managers, and the overall direction of the initiative are not clearly defined.

- Even though recent progress has been made, the Bureau is perceived to lack the capability to actively manage riparian areas. This inadequacy includes lack of training in options and clearly defined objectives and the lack of sufficient personnel and funds.

- Many people perceive that riparian problems cannot be solved because BLM lacks the financial and political capability to make major changes. 


\section{APPENDIX G}

\section{COMPARISON OF BLM FISHERIES PERSONNEL VERSUS AMOUNT OF FISH HABITAT BY STATE}

\section{Thousands \\ Acres of Lakes and Reservolrs \\ Per Blologist 1987}

Alaska

Arizona

California

Colorado

Idaho

Montana

Nevada

New Mexico

Oregon

Utah

Wyoming

Eastem States
1,291

No Staff

21

20

16

48

14

No Staff

4

6

37

No Staff
Miles of Fishable

Streams Per Blologlst 1987

21,667

No Staff

735

1,822

1,193

1,132

567

No Staff

649

1,150

1,327

No Staff 


\section{APPENDIX H \\ PUBLIC AFFAIRS PLAN}

The obectives of this Public Affairs Plan are to raise the awareness of BLM's fisheries habitiat management programs, both internally and externally; to encourage and enhance cooperation with resource interest groups; and to increase opportunities for volunteer participation.

\section{Action}

\section{National Level}

Prepare presentation for AFS meeting.

Coordinate BLM Public Affairs efforts with Nevada

Dept. of Wildlife and Utah Div. of Wildlife Resources.

Informal presentations and review by important conservation groups such as the American Fisheries Society, Wildlife Management Institute, National Wildlife Federation, etc.

Present report to Director and Bureau Management Team.

Write and issue news release on Memorandum of Understanding between BLM and Trout Unlimited.

Develop logo for fisheries program.

Write news release announcing completion and implementation of the report and distribute nationally.

Target key states for National Fishing Week activities, i.e., Utah, Neveda, Idaho.

Publish fisheries habitat story in national BLM newsletter (Inside Track).

Write script for national video tape on BLM fisheries program to be produced next fiscal year.

Work with Trout Unlimited to develop stories for Trout Magazine. Stories to include fisheries habitat on public lands; Memorandum of Understanding; fishing opportunities, e.g., cutthroat trout species in remote BLM public land areas.
The plan outlines actions to accomplish the objectives in a three-tiered approach: 1) headquarters level, 2) state office level, and 3) district and resource area level. Each state office public affairs staff should develop a local complement to the national public affairs plan and should issue guidance to districts and resource areas.

Responslbillity

Iarget Date

Team Leader 9/88

WO (130) 9/88

WO (240)

10/88

Team Leader

Team Leader

$12 / 88$

WO (130)

$12 / 88$

WO (854)

WO (240)

1/89

WO (130)

1/89

WO (240)

WO (130)

WO (130)

2/89

WO (240)/PTC

$3 / 89$

WO (130)

WO (240) 


\section{National Level (continued)}

Develop fact sheet on BLM fish resources that can be adapted for field office use. Include in National Fishing Week media kit.

Distribute media kits to BLM State Offices to promote National Fishing Week activities.

Develop segment for "BLM Magazine" video. Tie in with National Fishing Week.

Develop slide program that can be adapted for field office use.

\section{State Office Level}

Localize \& distribute national fisheries news releases.

Encourage cooperation of State fish and wildlife agencies and interest groups in developing complementary news releases.

Schedule and coordinate National Fishing Week event. Localize national media kit.

Distribute and localize (if desired) national slide show to showcase state projects.

Encourage BLM Districts to conduct field tours for interested parties.

\section{District and Resource Area Office Level}

Encourage and solicit volunteer opportunities.

Give presentations to local schools during National Fishing Week. Seek other opportunities to present BLM fisheries information, such as to local service groups and community gatherings.

Organize field tours for interest groups, Congressional staff, etc., and tie in with riparian education and demonstration areas.
WO (130)

WO (240)

WO (854)

WO (130)

WO (240)

WO (130)

$4 / 89$

WO (130)

WO (240)

$3 / 89$

$3 / 89$

$6 / 89$
State Public Affairs Officers

$1 / 89$

State Public Affairs Officers

SO Fish/Wildlife Staff

$1 / 89$

State Public Affairs Officers SO Fish/WildlifeStaff

4/89

State Public Affairs Officers

SO Fish/Wildlife Staff

SO Fish/Wildlife Staff

Continuing

District Public Affairs Officers Fish/Wildlife Staff

District Public Affairs Officers

District Biologists

Resource Area Biologists

District Managers

Area Managers

District Public Affairs Officers

$6 / 89$

Continuing

$6 / 89$

District Biologists

Resource Area Biologists

District Managers

Area Managers 


\section{APPENDIX I}

\section{FISHERIES TEAM MEMBERS}

Delmar Vail, Team Leader

Allan Thomas

Idaho State Office

Bureau of Land Management

3380 Americana Terrace

Boise, Idaho 83706

(208) 334-1401

\section{Roger Bolstad}

Kobuk District Office

Bureau of Land Management

1541 Gaffney Road

Fairbanks, AK 99703

(907) 356-5384

William A. Molini, Director

Nevada Department of Wildlife

P. O. Box 10678

Reno, Nevada 89520-0022

(702) 789-0500

William Geer, Director

Utah Division of Wildlife Resources

1596 West North Temple

Salt Lake City, Utah 84116-3154

(801) 533-9333, 530-1245

Paul Brouha, Deputy Director

American Fisheries Society

5410 Grosvenor Lane, Suite 110

Bethesda, MD 20814-2199

(301) $897-8616$
Dave Almand, Chief

Mike Crouse

Division of Wildlife \& Fisheries, WO 240

Bureau of Land Management

Premier Building, Room 903

Washington, D.C. 20240

(202) 653-9202

James Moorhouse

Butte District Office

Bureau of Land Management

P. O. Box 3388

Butte, MT 59702

(406) 494-5059

Paul Cuplin

Bureau of Land Management (retired)

12198 West Ohio Drive

Lakewood, Colorado 80228

(303) 986-2188

Neil Armantrout

Eugene District Office

Bureau of Land Management

P. O. Box 10226

Eugene, Oregon 97401

(503) 683-6451 


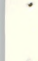


